GRASAS Y ACEITES 67 (2)

April-June 2016, e138

ISSN-L: 0017-3495

doi: http://dx.doi.org/10.3989/gya.0759152

\title{
Controlled fermentation of Moroccan picholine green olives by oleuropein-degrading Lactobacilli strains
}

\author{
N. Ghabbour ${ }^{\mathrm{a}, \bigotimes}$, Y. Rokni ${ }^{\mathrm{b}}$, Z. Lamzira ${ }^{\mathrm{b}}$, P. Thonart ${ }^{\mathrm{c}}$, N.E. Chihib $^{\mathrm{d}}$, C. Peres $^{\mathrm{e}}$ and A. Asehraou $^{\mathrm{b}}$ \\ ${ }^{a}$ Laboratoire des Matériaux, Substances Naturelles, Environnement \& Modélization (LMSNEM), Faculté \\ Polydisciplinaire de Taza, Université Sidi Mohamed Ben Abdellah de Fès, Maroc \\ ${ }^{b}$ Laboratoire de Biologie des Plantes et des Microorganismes, Faculté des Sciences, \\ Université Mohammed Premier, BP: 717, Oujda, Maroc \\ ${ }^{c}$ Unité de bio-industries, CWBI, Université de Liège, Agro-biotech, Gembloux, Belgique \\ INRA-UMR UMET 8207-Equipe PIHM, CNRS-INRA, Université de Lille, 369 rue jules Guesde, \\ BP20039, 59651 Villeneuve d'Ascq Cedex, France \\ ${ }^{e}$ Instituto Nacional dos Recursos Biológicos, L-INIA, Oeiras, Portugal \\ ${ }^{\square}$ Corresponding author: nabil.ghabbour@usmba.ac.ma
}

Submitted: 18 July 2015; Accepted: 12 January 2016

\begin{abstract}
SUMMARY: The control of the spontaneous fermentation process of un-debittered Moroccan Picholine green olives was undertaken basing the inoculation with two lactobacilli strains (Lactobacillus plantarum S175 and Lactobacillus pentosus S100). These strains, previously selected in our laboratory for their oleuropein-degrading capacity, were inoculated in olives brined at $5 \%$ of $\mathrm{NaCl}$, and then incubated at $30{ }^{\circ} \mathrm{C}$. The physico-chemical parameters ( $\mathrm{pH}$, free acidity, reducing sugars, sodium chloride, oleuropein and its hydrolysis products), and the microbiological parameters (mesophilic aerobic bacteria, coliforms, Staphylococcus, lactic acid bacteria and yeasts and moulds), were regularly analyzed during the fermentation time. The results obtained showed the effectiveness of the lactic acid bacteria strains to develop suitable oleuropein biodegradation and controlled lactic fermentation processes more than the un-inoculated olives (control). This result was confirmed by the rapid elimination of coliforms and staphylococcus, the accumulation of hydroxytyrosol as a result of oleuropein biodegradation, and a drastic reduction in spoiled olives with good quality fermented olives.
\end{abstract}

KEYWORDS: Fermentation; Green olives; Lactobacillus; Oleuropein; Starter

RESUMEN: Fermentación controlada de aceitunas verdes picholine marroquí mediante cepas de lactobacilos degradantes de oleuropeína. Se llevó a cabo el control del proceso de fermentación espontánea de aceitunas verdes sin desamargar picholine marroquí basado en la inoculación con dos cepas de lactobacilos (Lactobacillus plantarum S175 y Lactobacillus pentosus S100). Estas cepas, seleccionadas previamente en nuestro laboratorio por su capacidad de degradar a la oleuropeína, se inocularon en las aceitunas en salmuera al $5 \% \mathrm{de} \mathrm{NaCl}, \mathrm{y}$ después se incubaron a $30^{\circ} \mathrm{C}$. Los parámetros físico-químicos $(\mathrm{pH}$, acidez libre, reducción de azúcares, cloruro sódico, oleuropeína y sus productos de hidrólisis) y los parámetros microbiológicos (bacterias aerobias mesófilas, coliformes, estafilococos, bacterias lácticas y levaduras y mohos), fueron analizados regularmente durante el tiempo de fermentación. Los resultados obtenidos mostraron la eficacia de las cepas de bacterias lácticas para desarrollar una adecuada biodegradación de la oleuropeina y los procesos de fermentación láctica controlados más que en el caso de las aceitunas no inoculadas (control). Estos resultados fueron confirmados por la rápida eliminación de coliformes y estafilococos, por la acumulación de hidroxitirosol como resultado de biodegradación de la oleuropeína, y por ladrástica reducción de aceitunas estropeadas y por la buena calidad de las aceitunas fermentadas. 
PALABRAS CLAVE: Aceitunas; Fermentación; Iniciadores; Lactobacillus; Oleuropeína

Citation/Cómo citar este artículo: Ghabbour N, Rokni Y, Lamzira Z, Thonart P, Chihib NE, Peres C, Asehraou A. 2016. Controlled fermentation of Moroccan picholine green olives by oleuropein-degrading Lactobacilli strains. Grasas Aceites, 67 (2): e138. doi: http://dx.doi.org/10.3989/gya.0759152.

Copyright: (C2016 CSIC. This is an open-access article distributed under the terms of the Creative Commons Attribution-Non Commercial (by-nc) Spain 3.0 Licence.

\section{INTRODUCTION}

The natural lactic fermentation of green olives is a complex process. It is mainly based on a spontaneous fermentation characterized by its long duration and frequently associated with high spoilage incidence in olives, and leads to an end product with varying quality (Fernandez-Diez et al., 1985). The fermentation process is naturally associated with the development of various microorganisms. The lactic acid bacteria (LAB) and yeasts considered as beneficial microorganisms are highly desired to assure the fermentation process of olives which consequently leads to their transformation to edible products, in comparison to the role played by undesirable microbiota, composed of enterobacteria, Bacillus and moulds, known for their involvement in various olive spoilages (Fernández-Diez et al., 1985, Garrido-Fernández et al., 1997, Arroyo-López et al., 2012, Hurtado et al., 2012). The control of the natural olive fermentation process with selected LAB strains is of great importance to reduce olive spoilage and to improve the organoleptic properties of the end product.

Green olives are not edible without the elimination of bitterness, due to their natural polyphenols, mainly oleuropein. This polyphenol is known for its antimicrobial activity against various microorganisms, particularly LAB (Juven B. et al., 1968, Fleming and Etchells, 1967, Fleming et al., 1973, Furneri et al., 2002, Ruiz-Barba et al., 1990, Ruiz-Barba et al., 1991, Ruiz-Barba et al., 1993, Landete et al., 2008, Medina et al., 2009, Rodríguez et al., 2009) which is highly desired to assure the natural lactic fermentation of green olives. The main LAB involved in this process is composed of L. plantarum, L. pentosus, L. brevis, Leuconostoc and Pediococcus (Durán Quintana et al., 1997, Rodríguez et al., 2009). Among these species Lactobacillus plantarum and L. pentosus were reported as effective starters to allow for a controlled fermentation of table olives (Lamzira et al., 2005, Marsilio et al., 2005, Panagou et al., 2008, Sabatini et al., 2008, Servili et al., 2006, Hurtado et al., 2012).

The tolerance and bio-degradation of oleuropein by certain strains of LAB was demonstrated (Ciafardini et al., 1994, Rozes and Peres, 1996, Marsilio et al., 1996, Marsilio and Lanza, 1998). In a previous work we have selected strains of $L$. plantarum and L. pentosus to show the in-vitro bio-degradation capacity of oleuropein (Ghabbour et al., 2011). Their application in un-debittered olive fermentation may improve the nutritional, organoleptic and functional properties of the end product by reducing the nutrient losses due to the de-bittering and washing of the olives, and producing fermented olives rich in LAB cells and their metabolism products. The main objective of this work was to control the natural fermentation process of un-debittered Moroccan Picholine green olives by LAB inoculation, using two lactobacilli strains previously selected for their oleuropein biodegradation capacity. The inoculation was performed in non-sterilized olives in order to evaluate the capacity of the lactobacilli strains to improve the natural fermentation process, widely practiced at the industrial level.

\section{MATERIALS AND METHODS}

\subsection{Olive preparation}

Green olives of the Moroccan Picholine variety were purchased at a market in the Oujda area (east of Morocco). The olives were sorted manually, and then $400 \mathrm{~g}$ of olives were brined at 5\% (w/v) of $\mathrm{NaCl}$, in flasks with a volume of about $494 \mathrm{~mL}$, and then adjusted to $\mathrm{pH} 6$ with lactic $\operatorname{acid}(0.1 \mathrm{~N})$.

\subsection{Starter preparation and olive inoculation}

The starters were prepared with two separate lactobacilli strains (L. plantarum S175 and L. pentosus S100) previously selected for their in-vitro oleuropein bio-degradation capacity (Ghabbour et al., 2011). The strains were cultivated twice in MRS broth containing $5 \%(\mathrm{w} / \mathrm{v})$ sodium chloride and incubated overnight at $30^{\circ} \mathrm{C} .1 .5 \mathrm{~mL}$ of each MRS culture was diluted in a brine solution containing sodium chloride $(5 \%, \mathrm{w} / \mathrm{v})$ and then used to inoculate $100 \mathrm{ml}$ of brine to obtain a final concentration of about $10^{7}-10^{8} \mathrm{cfu} \cdot \mathrm{mL}^{-1}$. The inoculation of the olives was done 24 hours after their brining. The assays were carried out as follows: (assay 1): un-inoculated control (spontaneous fermentation), (assay 2): olives inoculated with L. plantarum S175 and (assay 3): olives inoculated with $L$. pentosus S100. The assays, made in duplicate, were incubated at $30{ }^{\circ} \mathrm{C}$. The brines regularly and aseptically 
sampled were subjected to physicochemical and microbiological analyses.

\subsection{Microbiological analysis}

The brines sampled were subject to successive decimal dilutions in sterile saline water. From the decimal dilutions, each microbial group was inoculated in its specific medium, using the pourplate method. The mesophilic aerobic bacteria, coliforms, staphylococci, lactic acid bacteria, and yeasts and moulds were determined, respectively, on Trypticase Soya Agar pH 7.3 \pm 0.2 (Biokar, France), Deoxycholate lactose agar $\mathrm{pH} 7.3 \pm 0.2$ (Biokar, France), chapman medium pH 7.4 \pm 0.2 (Biokar, France), de Man Rogosa \& Sharpe agar pH 5.7 \pm 0.1 (Biokar, France) containing pimaricin at $0.02 \%$, and potato dextrose agar (Biokar, France) acidified with lactic acid $(0.1 \mathrm{~N})$ to $\mathrm{pH}$ 3.5. The mesophilic aerobic bacteria and staphylococci were counted after 2 days of incubation at $30^{\circ} \mathrm{C}$. The coliforms were counted after 2 days of incubation at $37^{\circ} \mathrm{C}$. The LAB were counted after 3 days of incubation at $30^{\circ} \mathrm{C}$. The yeasts and moulds were counted after 3 to 4 days of incubation at $25^{\circ} \mathrm{C}$.

\subsection{Physico-chemical analysis}

The physicochemical parameters analyzed in the brine samples were $\mathrm{pH}$, free acidity, chloride and sugars. The $\mathrm{pH}$ was measured using a $\mathrm{pH}$ meter type Crison pH 2000 after calibration at $\mathrm{pH} 4$ and 7 . The free acidity was determined using $\mathrm{NaOH}(0.1 \mathrm{~N})$ and phenolphthalein as indicator. The results were expressed as percent of lactic acid. The chloride content in brine was measured by titration with $\mathrm{AgNO} 3(0.1 \mathrm{~N})$ in the presence of potassium chromate $(0.5 \%, \mathrm{w} / \mathrm{v})$ as indicator, the content of chloride in the brine was determined based on a standard curve made with $\mathrm{NaCl}$, and expressed as percent of $\mathrm{NaCl}$. The soluble sugar contents expressed in $\mathrm{g}$ per $100 \mathrm{~mL}$ of brine, were determined using the Ashwell method (Ashwell, 1957), based on the measurement of the green color developed by the reaction of soluble sugars with anthrone in the presence of sulphuric acid. The green color developed was measured at 630 $\mathrm{nm}$. The results obtained were expressed in grams of total sugars per $100 \mathrm{~mL}$ of brine.

\subsection{Polyphenols analysis}

The brines of all the inoculated assays weres ampled in triplicate ont the $1^{\text {st }}, 5^{\text {th }}, 10^{\text {th }}, 15^{\text {th }}, 23^{\text {th }}$ and at the $38^{\text {th }}$ day of the fermentation process; the brines of the control assay were sampled on the $1^{\text {st }}$ and the $38^{\text {th }}$ day of the fermentation process. The sampled brines were analyzed by HPLC-DAD for their oleuropein and hydrolysis product contents. The samples were centrifuged at $1000 \mathrm{rpm} / 10 \mathrm{~min}$, and phenolic compounds were extracted from the supernatant three times with ethyl acetate $(8: 2, v / v)$. After decanting, the organic phase was harvested and left in the dark for 30 minutes in the presence of disodium sulfate, and then evaporated to dryness at $50{ }^{\circ} \mathrm{C}$. The residue obtained was dissolved in $1 \mathrm{~mL}$ of methanol and stored at $-20^{\circ} \mathrm{C}$ and then analyzed by an HP isocratic HPLC, equipped with an HP-UV detector at $280 \mathrm{~nm}$ and a C18 column $(250 \mathrm{~mm} \times 4,6 \mathrm{~cm}, 5 \mu \mathrm{m})$ maintained at $40{ }^{\circ} \mathrm{C}$. The mobile phase consisted of a milli-Q water acidified with acetic acid $(97: 3, \mathrm{v} / \mathrm{v})$ (solution A) and acetonitryl-methanol $(1: 1, \mathrm{v} / \mathrm{v})$ (solution B). The samples were filtered through a PVDF syringe filter (Sartorius, France), and then a volume of $20 \mu \mathrm{L}$ was injected at a flow rate of $1 \mathrm{~mL} \cdot \mathrm{min}^{-1}$. The solvent gradient changed according to that reported by (Kaltsa et al., 2015). The identification of polyphenolic compounds in olive brines was carried out by comparing the retention times of each peak with those of oleuropein and hydroxytyrosol standards. Phenolic compound quantification was achieved by measuring the absorbance at $280 \mathrm{~nm}$ recorded in the chromatograms relative to external standards.

\subsection{Tentative examination of the sensory characteristics}

At the end of the fermentation process, all the fruits were sorted manually and examined for their attack by olive spoilage. The fermented olive properties, including off-odor, bitterness, acid taste, hardness and crunchiness, were assessed by 20 panelists composed of teachers and doctorate degree students in our university, not by specialized panelists, and compared to a commercial sample of green olives fermented according to the Spanish process. The sensorial evaluation was indicated using a line scale ranging from 0 (no perception) to 10 (extreme) as described by (Meilgaard et al., 1991). From each sample, 4 olives were tasted for the evaluation. Between each tasting the panelists washed their mouths out with mineral water.

\subsection{Statistical analysis}

All the determinations were carried out in triplicate and the results were expressed as mean values and standard mean error. Data were analyzed by an analysis of variance (ANOVA). Means were compared using the One-way ANOVA with Tukey's post tests and the Two-way ANOVA with Bonfferoni's post tests, using GraphPad Prism version 5.00 for Windows, GraphPad Software, San Diego California USA. The significant level was set at $5 \%(\mathrm{p}<0.05)$. 


\section{RESULTS AND DISCUSSION}

\subsection{Microbiological analysis}

During the first 2 weeks of the process all the assays showed a rapid development of the microbiota associated with olives, to achieve $7.6-9.810^{8} \mathrm{cfu} /$ $\mathrm{ml}$ for $\mathrm{LAB}$ and mesophilic microbiota, and $3-510^{6}$ $\mathrm{cfu} \cdot \mathrm{mL}^{-1}$ for yeasts and moulds, and after a reduction to stabilize, around $10^{5} \mathrm{cfu} \cdot \mathrm{mL}^{-1}$ until the end of the fermentation process (Figure 1).

Significant differences were observed when inoculated olives (with L. plantarum S175 or with L. pentosus S100) and un-inoculated olives (control) were compared. The interaction between inoculation and time effects significantly affected $(p<0.001)$ the evolution of the LAB population. This population of inoculated olives showed a slight increase from $5.7-910^{7}$ to about $10^{9} \mathrm{cfu} \cdot \mathrm{mL}^{-1}$ during the first 15 days of the process, followed by a decrease to stabilize at around $2.10^{5} \mathrm{cfu} \cdot \mathrm{mL}^{-1}$ at the end of the process (Figure 1). The natural LAB population of the un-inoculated olives (control) showed a rapid development from about $10^{2} \mathrm{cfu} \cdot \mathrm{mL}^{-1}$ to achieve $1.210^{6} \mathrm{cfu} \cdot \mathrm{mL}^{-1}$ during the first 20 days, followed by a slight decrease to stabilize at $1.810^{4} \mathrm{cfu} \cdot \mathrm{mL}^{-1}$ at the end of the fermentation process. This decrease may be due to the elimination of the LAB species non-supporting high acidity values (Balatsouras, 1985) and polyphenols (Landete et al., 2008, Rodríguez et al., 2009) accumulating during the fermentation process. In accordance with (Panagou et al., 2003), the results obtained showed a better performance of selected lactobacilli strains (L. plantarum S175 and L. pentosus S100) in developing a good fermentation process by dominating the yeast biochemical activity and leading to the improvement of the hygienic quality of fermented olives. The final concentration of LAB cells $\left(210^{5} \mathrm{cfu} \cdot \mathrm{mL}^{-1}\right)$ obtained in fermented olives is of great importance for developing the functional properties of the end product since this microbiota is responsible for the flavor and the texture of the end products (Garrido-Fernández et al., 1997, Sánchez et al., 2000).

The yeast and mould populations of all the assays showed a rapid development during the first 15 days of the fermentation process to achieve a maximum of 3-5 $10^{6} \mathrm{cfu} \cdot \mathrm{mL}^{-1}$ (Figure 1). After this first phase, the yeast population showed a slight decrease to stabilize at around $10^{5} \mathrm{cfu} \cdot \mathrm{mL}^{-1}$ until the end of the fermentation process. Slight differences in yeast and mould and mesophilic microbiota evolutions were observed in the inoculated olives compared to the un-inoculated olives (control). The inoculation of olives with $L$. plantarum showed significant differences in the evolution of the yeast and mould population during the first four weeks compared to un-inoculated olives (control), but no significant differences were observed towards the end of the process. However, the inoculation with $L$. pentosus S100 showed a significant effect on this population at some different times of the process in comparison with the olives inoculated with L. plantarum S175 and the un-inoculated olives (control).

The active development of the yeast and mould population during the first days of fermentation may be due to the accumulation of nutrients and low concentrations of polyphenols. This microbiota can play a double role as fermentative and spoilage microorganisms in olive fermentation (Arroyo-López et al., 2008). Their presence at the beginning of fermentation can improve the growth of LAB (Tsapatsaris and Kotzekidou, 2004, Hurtado et al., 2012). Their decrease during the second phase of the fermentation may lead to important organoleptic attributes, determining the quality and flavor of the end product, and may improve the dominance of the biochemical activity

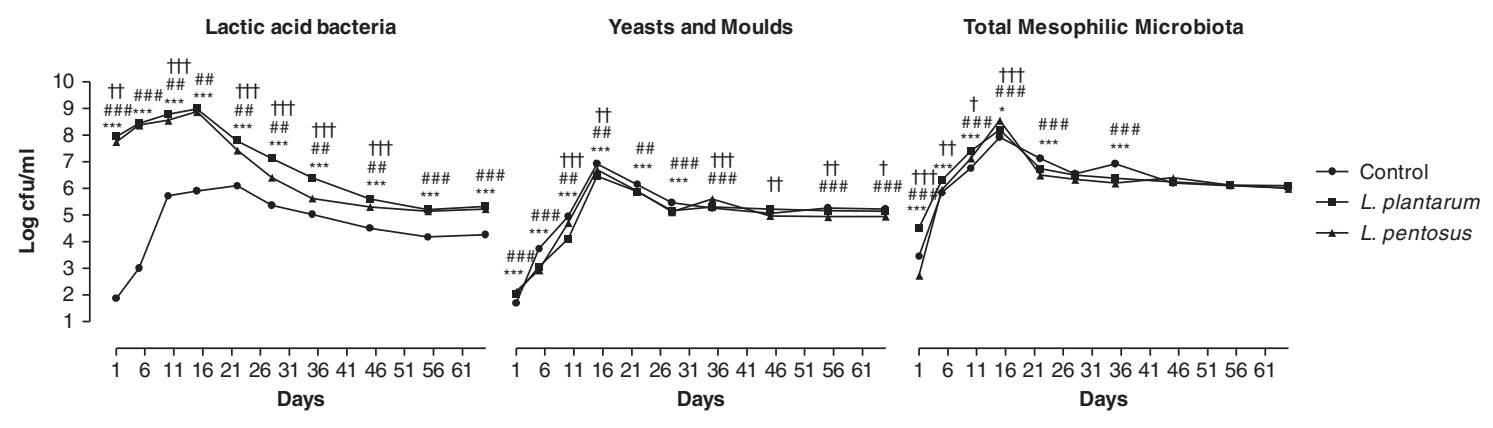

FIGURE 1. Evolution of lactic acid bacteria, yeasts and moulds, and total mesophilic microbiota in olive brines during fermentation at $30{ }^{\circ} \mathrm{C}$. - Control: un-inoculated green olives (spontaneous fermentation), - L plantarum: Green olives inoculated with Lactobacillus plantarum S175strain, _ _ - L. pentosus: Green olive inoculated with Lactobacillus pentosus S100 strain. *Values (L. plantarum vs Control), ${ }^{*}$ Values (L. pentosus vs Control), ${ }^{\dagger}$ Values (L. plantarum vs L. pentosus). ${ }^{*}, \#, \dagger$ Values differ significantly $(\mathrm{p}<0.05),{ }^{* *}, \# \#,{ }^{\dagger \dagger}$ Values differ significantly $(\mathrm{p}<0.01),{ }^{* * *}, \# \#$, , ${ }^{\dagger \dagger}$ Values differ significantly $(\mathrm{p}<0.001)$ 
of LAB which is highly desired to assure the olive biotransformation.

The coliform population showed, in inoculated assays, a rapid development from about $10^{2} \mathrm{cfu} \cdot \mathrm{mL}^{-1}$ to achieve a maximum of $3.6-710^{3} \mathrm{cfu} \cdot \mathrm{mL}^{-1}$ during the first 5 days, followed by a drastic reduction and elimination at the end of the second week of fermentation (Figure 2). The un-inoculated olives (control) showed the same appearance, but with a delay of about 10 days in comparison with inoculated olives. The staphylococci population showed, in all the assays, a rapid development during the first 10 days of fermentation, followed by a drastic reduction and elimination at the third week of fermentation (Figure 2). Two-way ANOVA with Bonfferoni's post tests data revealed that the inoculation of olives (with L. plantarum S175 and L. pentosus S100) significantly affected the evolution of coliforms and staphylococci populations, while the LAB strains used as starter grew during the fermentation process. This finding is in agreement with the results obtained by (Benincasa et al., 2015), indicating the presence of $L$. plantarum starter throughout the fermentation process, while staphylococci and coliforms disappeared after 30 and 90 days of fermentation, respectively. The elimination of these populations leads to the improvement in the hygienic quality of fermented olives. It may be due to the antimicrobial compounds and to a progressive acidification of the fermenting brine produced by lactic acid bacteria (Klaenhammer et al., 1994, Marsilio et al., 2005) and to the oleuropein and its hydrolysis products (Nychas et al., 1990).The reduction in the mesophilic microbiota population downstream of the fermentation process should lead to the stabilization of the end product during the post fermentation phase.

\subsection{Physicochemical analysis}

The inoculated olives, with L. plantarum S175 or $L$. pentosus $\mathrm{S} 100$, showed a rapid drop in $\mathrm{pH}$ from 6 to 4.5 during the first 5 days of fermentation, followed by a slight reduction to stabilize at around $\mathrm{pH} 4$ until the end of the fermentation process (Figure 3). The un-inoculated olives (control) showed the same trend with higher $\mathrm{pH}$ values than those obtained in inoculated olives. The free acidity showed a continuous increase in all assays to achieve, at the end of the fermentation process, $0.9 \%$ and $1 \%$ in olives inoculated respectively with L. pentosus $\mathrm{S} 100$ and L. plantarum $\mathrm{S} 175$, and $0.5 \%$ in the control (Figure 3). Throughout the fermentation process, the acidity values obtained in the inoculated olives were higher than those of the control.

Significant differences $(\mathrm{p}<0.001)$ in $\mathrm{pH}$ and acidity values were observed during the fermentation process when the inoculated and un-inoculated olives were compared. However, no significant differences were observed, during 45 days of the process, between assays inoculated with $L$. plantarum $\mathrm{S} 175$ and L. pentosus $\mathrm{S} 100$. These differences in $\mathrm{pH}$ and acidity changes between the controlled process (inoculated olives) and spontaneous process (uninoculated olives), particularly the rapid acidification, indicate the rapid installation and acidification rates of the LAB strain over the microbiota naturally associated with the spontaneous process.

L. plantarum and L. pentosus were demonstrated to have a high acidification rate in the controlled fermentation of Portuguese Azeiteira and Arbequina green olive varieties (Hurtado et al., 2010, Peres et al., 2008).Other authors reported a faster acidification of inoculated Manzanilla green olives with

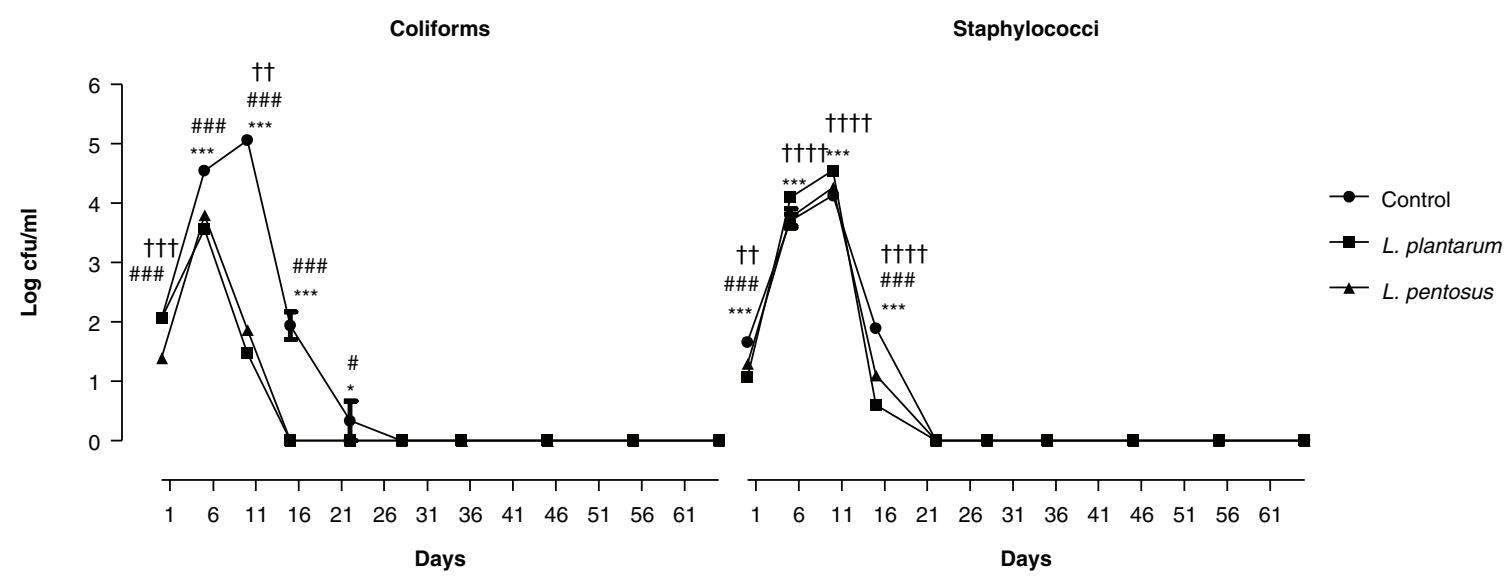

FIGURE 2. Evolution of coliforms and staphylococci in olive brines during fermentation at $30^{\circ} \mathrm{C}$. - - Control: un-inoculated green olives (spontaneous fermentation), L plantarum: Green olives inoculated with Lactobacillus plantarum S175strain, - - L . pentosus: Green olives inoculated with Lactobacillus pentosus $\mathrm{S} 100$ strain. Values (L. plantarum vs Control), ${ }^{\#}$ Values (L. pentosus vs Control), ${ }^{\dagger}$ Values (L. plantarum vs L. pentosus). ${ }_{*}^{* \#, ~}{ }^{\dagger}$ Values differ significantly $(\mathrm{p}<0.05),{ }^{* *}, \# \#,{ }^{\dagger \dagger}$ Values differ significantly $(\mathrm{p}<0.01),{ }^{* * *}, \# \#,+\dagger \dagger$ Values differ significantly $(\mathrm{p}<0.001)$. 

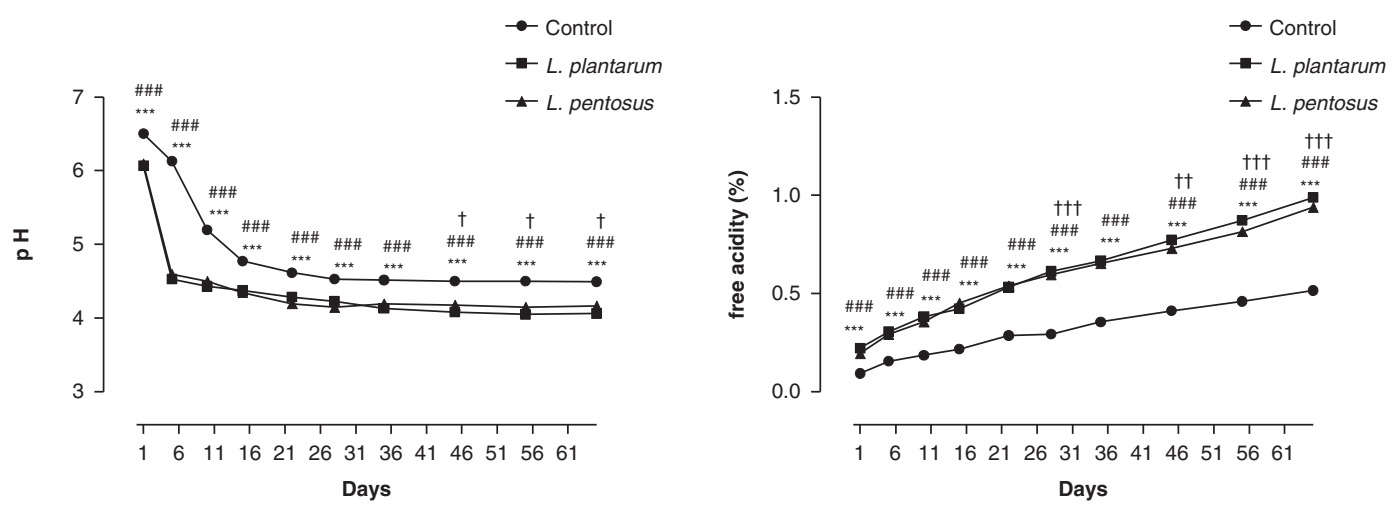

FIgURE 3. Evolution of $\mathrm{pH}$ and free acidity (\% lactic acid) in olive brines incubated at $30^{\circ} \mathrm{C} . \longrightarrow-$ Control: un-inoculated green olives (spontaneous fermentation), - - L plantarum: Green olives inoculated with Lactobacillus plantarum S175strain, - - - L. pentosus: Green olives inoculated with Lactobacillus pentosus S100 strain. "Values (L. plantarum vs Control),

"Values (L. pentosus vs Control), ${ }^{\dagger}$ Values (L. plantarum vs L. pentosus). ${ }^{*}, \#, \uparrow$ Values differ significantly $(\mathrm{p}<0.05)$,

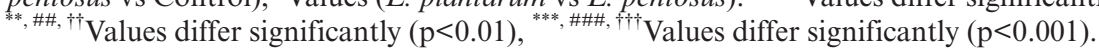
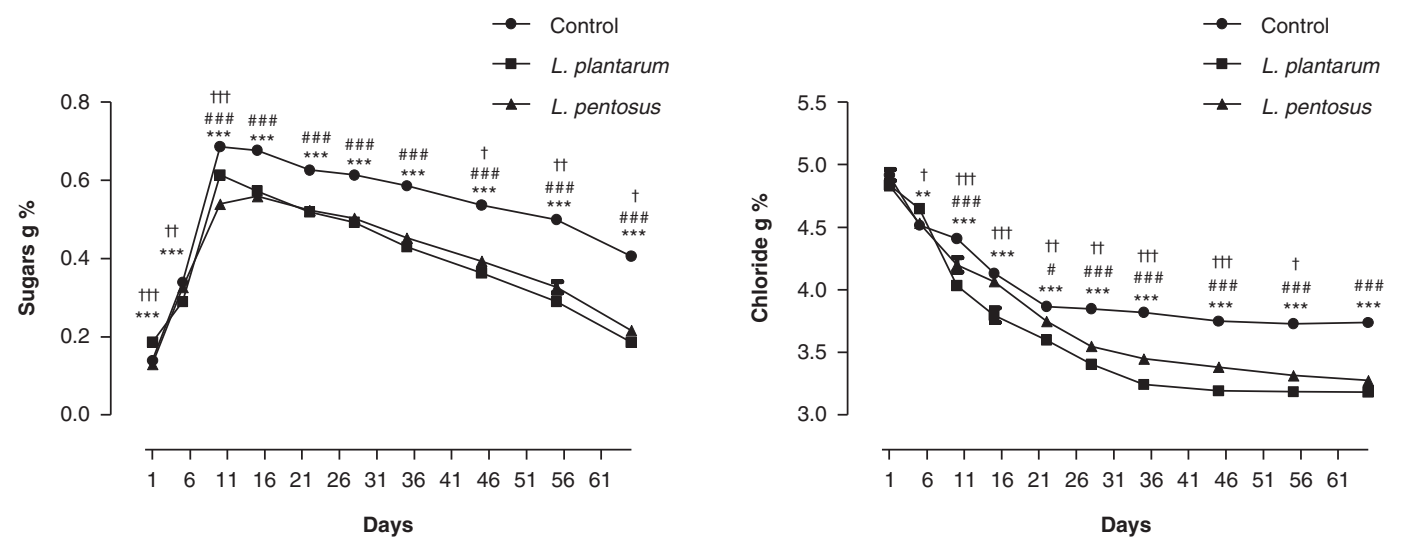

FIGURE 4. Evolution of sugars and chloride contents in olive brines incubated at $30{ }^{\circ} \mathrm{C}$ in olive brines incubated at $30{ }^{\circ} \mathrm{C}$.

Control: un-inoculated green olives (spontaneous fermentation), - L. plantarum: Green olives inoculated with Lactobacillus plantarum S175strain, _- - L pentosus: Green olive inoculated with Lactobacillus pentosus S100strain. *Values (L. plantarum vs Control), ${ }^{\#}$ Values (L. pentosus vs Control), ${ }^{\dagger}$ Values (L. plantarum vs $L$. pentosus). ${ }^{*, \#, \dagger}$ Values differ significantly $(\mathrm{p}<0.05)$, ${ }^{* *}, \# \#, \dagger \dagger$ Values differ significantly $(\mathrm{p}<0.01),{ }^{* * *}, \# \#,+\dagger \dagger$ Values differ significantly $(\mathrm{p}<0.001)$.

L. plantarum higher than the spontaneous process during the first 25 days of brining (Leal-Sánchez et al., 2003).

The increase in acidity may be due to the microbial activity of mesophilic acid producing microorganisms, mainly LAB, spore forming bacteria, coliforms, and fermentative yeasts (Balatsouras, 1985, Fernández-Diez et al., 1985). The biochemical activity of these microorganisms may be activated by the optimal temperature of incubation maintained at $30{ }^{\circ} \mathrm{C}$, and high contents of sugars and other nutrients in brines, due to their rapid infiltration from olives to brine. The acidity values obtained are highly desired to improve the hygienic quality of the end product, since the pathogenic bacteria are sensible and rapidly eliminated in acidic conditions
(Peres et al., 2008, Panagou et al., 2008). Indeed, the rapid acidification of the brines induced by the $\mathrm{LAB}$ starter may increase the prevalence of $\mathrm{LAB}$ in the epiphytic population and may reduce the risk of pathogen growth in intestinal tract of the consumer. These actions improve the safety and the pro-biotic properties of fermented olives.

The sugar contents showed, in all the assays, a rapid increase during the first 10 days of fermentation, to achieve a maximum of around $0.6 \%$, and decrease continuously throughout the process to $0.3 \%$ in the un-inoculated olive (control) and $0.1 \%$ in the inoculated olives (Figure 4). The inoculation of olives with $L$. plantarum or with $L$. pentosus significantly affected the evolution of sugars during the fermentation process. High sugar contents were 
detected in un-inoculated olives (control) in comparison with inoculated olives. Sugars are required for fermentation installation, and their diffusion from fruit to brine depends on various parameters like skin permeability, salt concentration, olive variety and temperature (Garrido-Fernández et al., 1997). There is a relative correlation between the consumption of sugars and the accumulation of lactic acid. This result may be due to the high microbial activity, mainly the acidification rate observed in inoculated olives.

The chloride contents showed a decrease in olive brines, in all the assays, during the fermentation process to stabilize at the end of the process at around $3.3 \%$ in inoculated olives and $3.8 \%$ in un-inoculated olives (control) (Figure 4). Significant differences in the final chloride contents were observed between inoculated olives and the control. This difference may be due to the osmosis exchange of polyphenols and sodium chloride between olive flesh and brine; these exchanges are more expressed in inoculated olives where the oleuropein released from fruits is subject to biodegradation by the starter. Significant differences were observed in some points of the fermentation process when the types of inoculation were compared. The decrease in chloride contents is due to their infiltration from brine into olive flesh until achieving the equilibrium, this infiltration of chloride into olive flesh is of great interest since it facilitates the release of oleuropein from olives to the brine (Ozdemir et al., 2011), which accelerates their de-bittering process. The salt content may influence the fermentation process by affecting the growth of lactic acid bacteria (Leal-Sánchez et al., 2003). The low salt content $(5 \%$ of $\mathrm{NaCl})$ we used in olive brining may allow a faster growth of the LAB starter without affecting biochemical activity, particularly the biodegradation of oleuropein (Romeo and Poiana, 2007).

\subsection{Polyphenol analysis}

To measure the degree of oleuropein disappearance, the oleuropein and hydroxytyrosol in brine were monitored. The results of the polyphenol analysis by HPLC-DAD are reported in (Table 1). The oleuropein and hydroxytyrosol contents were expressed in $\mathrm{mg}$ per $100 \mathrm{ml}$ of olive brine. The oleuropein was the major phenolic compound found in the olive brines at the onset of the fermentation process. During the first 5 days of fermentation, the oleuropein content decreased from about 84.9 to $39.6 \mathrm{mg}$ per $100 \mathrm{~mL}$ of brine and from 72.7 to 42.8 $\mathrm{mg}$ per $100 \mathrm{~mL}$ of brine, respectively in the inoculated olives with L. plantarum S175 and L. pentosus S100. This reduction of oleuropein was accompanied by a simultaneous increase in the hydroxytyrosol content from about 11.1 to $64.5 \mathrm{mg}$ per $100 \mathrm{~mL}$ of brine and from 10.8 to $69.9 \mathrm{mg}$ per $100 \mathrm{~mL}$ of brine, in inoculated olives with L. plantarum S175 and $L$. pentosus $\mathrm{S} 100$, respectively.

The oleuropeinolytic activity obtained with both lactobacilli strains is significantly higher than the control (un-inoculated olives). This result indicates the high involvement of the LAB starter in oleuropein degradation. During the lactic fermentation process the degradation of oleuropein may be attributed to the acidic condition and the $\beta$-glucosidase, related to the biochemical activity of the LAB starter (Brenes et al., 1993).

From the $5^{\text {th }}$ day of the fermentation process, the accumulation of oleuropein in inoculated brines exceeds its degradation rate. This result may be explained by the higher and continuous diffusion of oleuropein by osmosis from olive flesh to the brine (Ozdemir et al., 2011), which is higher than its biodegradation by LAB strains, indicated by a continuous increase of hydroxytyrosol in the brine. Hence, the hydroxytyrosol contents increased

TABLE 1. Evolution of Oleuropein and Hydroxytyrosol contents in olive brines during the fermentation process of inoculated and un-inoculated olives. (nd : not determined)

\begin{tabular}{|c|c|c|c|c|c|c|c|}
\hline \multirow[t]{2}{*}{ Inoculated Green Olive } & \multirow[t]{2}{*}{ Days } & 1 & 5 & 10 & 15 & 23 & 38 \\
\hline & & \multicolumn{6}{|c|}{ Concentrations of Oleuropein and Hydroxytyrosol $\left(\mathrm{mg} \cdot 100 \mathrm{~mL}^{-1}\right.$ of olive brine $) \pm$ ESM } \\
\hline L. plantarum 175 & Oleuropein & 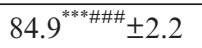 & $39.6^{\mathrm{ns}} \pm 3.1$ & $79.1^{* * *} \pm 3.5$ & $133.3^{* * *} \pm 1.5$ & $159.6^{* * *} \pm 1.6$ & 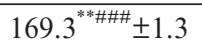 \\
\hline L. pentosus $\mathrm{S} 100$ & Oleuropein & $72.7^{\dagger \dagger \dagger} \pm 0.7$ & $42.8 \pm 0.1$ & $57.9 \pm 0.6$ & $106.1 \pm 0.6$ & $149 \pm 0.3$ & $176.6^{\dagger \dagger} \pm 0.3$ \\
\hline Un-inoculated olive & Oleuropein & $94 \pm 0.4$ & nd & nd & nd & nd & $193 \pm 0.2$ \\
\hline L. plantarum 175 & Hydroxytyrosol & $11.1^{\mathrm{nnns}} \pm 0.9$ & $64.5^{\mathrm{ns}} \pm 1.9$ & $94.7^{* * *} \pm 7$ & $122.2^{\mathrm{ns}} \pm 3.5$ & $132.9^{*} \pm 3.1$ & 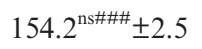 \\
\hline L. pentosus $\mathrm{S} 100$ & Hydroxytyrosol & $10.8^{\mathrm{ns}} \pm 0.1$ & $69.9 \pm 0.6$ & $118 \pm 0.7$ & $128.6 \pm 0.8$ & $142.7 \pm 1.3$ & $160.6^{\dagger \dagger \dagger} \pm 0.3$ \\
\hline Un-inoculated olive & Hydroxytyrosol & $3 \pm 0.2$ & nd & nd & nd & nd & $42 \pm 0.4$ \\
\hline
\end{tabular}

${ }^{*}$ Values (L. plantarum 175 vs L. pentosus S100), ${ }^{\#}$ Values (L. plantarum 175 vs Control), ${ }^{\dagger}$ Values (L. pentosus S100 vs Control).

$*, \#, \dagger$ Values differ significantly $(\mathrm{p}<0.05)$.

$* *, \# \#, \dagger$ Values differ significantly $(\mathrm{p}<0.01)$.

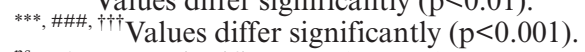

${ }^{\mathrm{n} s}$ Values not significant at $(\mathrm{p}<0.05)$. 
from $11.1-10.8 \mathrm{mg}$ per $100 \mathrm{~mL}$ of brine initially to $154.2-160.6 \mathrm{mg}$ per $100 \mathrm{ml}$ of brine as final concentrations were obtained after 38 days of culture with L. plantarum $\mathrm{S} 175$ and L. pentosus S100, respectively; while the un-inoculated olives showed an increase of hydroxytyrosol from $3 \mathrm{mg}$ per $100 \mathrm{~mL}$ of brine initially to $42 \mathrm{mg}$ per $100 \mathrm{~mL}$ of brine after 38 days of fermentation. The oleuropein contents, obtained after 38 days of culture with L. plantarum S175 and L. pentosus S100, were respectively of $169.3 \mathrm{mg}$ per $100 \mathrm{~mL}$ of brine and $176.6 \mathrm{mg}$ per $100 \mathrm{ml}$ of brine, while un-inoculated olives showed $193 \mathrm{mg}$ of oleuropein per $100 \mathrm{ml}$ of brine. The higher contents of hydroxytyrosol found in the inoculated olive brine with L. plantarum S175 and L. pentosus S100 which were respectively154.2 mg per $100 \mathrm{~mL}$ and160.6 mg per $100 \mathrm{ml}$ of brine as final concentrations were obtained after 38 days of culture, compared to that obtained in the un-inoculated control (42 mg per $100 \mathrm{~mL}$ ), confirms the oleuropeinolitic activity of the starter. These results indicate the possible use of these LAB strains, instead of chemicals, in the biological de-bittering of green olives.

Hydroxytyrosol was reported as the main product of oleuropein biodegradation by lactic acid bacteria (Ciafardini et al., 1994, Landete et al., 2008, Rodríguez et al., 2009, Zago et al., 2013, Benincasa et al., 2015). It is considered a marker to determine the oleuropein degradation and the diffusion of phenols from drupes to brine (Randazzo et al., 2011). Its accumulation in brine may be due to the oleuropeinolytic activity of the LAB starter and other microorganisms naturally associated with the fermentation process (Garrido-FernÁndez and Vaughn, 1978, Kaltsa et al., 2015). These microorganisms with $\beta$-glucosidase and esterase activities are useful for table olives bio-processing by assuring the biological de-bittering and fermentation of olives, instead of a chemical process.

L. plantarum was reported as a potentially active species in the biological de-bittering and lactic fermentation process of olives (Landete et al., 2008, Rodríguez et al., 2009, Zago et al., 2013, Benincasa et al., 2015, Kaltsa et al., 2015). However, the LAB starter activity may depend on the LAB species and olive variety. L. plantarum was reported to be unsuitable for controlled fermentation of Arbequina green olives, while L. penstosus was suitable for Arbequina and Leccinocv olive processing (Servili et al., 2006, Hurtado et al., 2010). These authors demonstrated that L. pentosus improved the fermentation process by reducing entero-bacteria survival during the first stage of fermentation and modifying the sensorial quality of fermented olives. In our study, both LAB strains of L. plantarum S175 and L. pentosus S100, showed high adaptation and biochemical activities, with a slight difference in oleuropein biodegradation and the lactic fermentation installation of the non alkali-treated Moroccan Picholine green olive variety. This result indicates their possible use as autochthonous LAB starters for the industrial biological processing of this local variety.

\subsection{Tentative examination of sensory characteristics}

The main olive spoilage identified in fermented olives was the bloater, called "gas pocket". The bloater incidences obtained were $9 \%$ and $12 \%$ in inoculated olives with L. plantarum S175 and L. pentosus S100, respectively. However, higher bloater incidence (34\%) was obtained in un-inoculated olives. Compared to the control (un-inoculated olives), the lower bloater incidences obtained in inoculated olives indicate the effectiveness of the LAB starter tested in controlling the natural fermentation process.

The bloater spoilage is due mainly to the gas producing microorganisms, including coliforms, fermentative yeasts and hetero-fermentative LAB (Asehraou et al., 2000). The low level of bloater incidence obtained in inoculated olives may be explained by the rapid elimination of coliforms, and the reduction in hetero-fermentative LAB and fermentative yeast activities, mainly due to the dominance of the biochemical activity of LAB starters (L. plantarum $\mathrm{S} 175$ and $L$. pentosus $\mathrm{S} 100$ ) over the other fermentative microorganisms. LAB are known for their anti-microbial production capacity (organic acids, bacteriocins and hydrogen peroxide) (Marsilio et al., 2005, Reis et al., 2012).

All the panelist members preferred the taste of the inoculated olives as good palability products than the un-inoculated, market olives. No off-odors were detected by panelists in any of the samples of fermented olives. However different levels of the other sensory attributes were revealed. Bitterness, acidic taste, hardness and crunchiness analyses were significantly inoculation-dependent. The one way ANOVA data with Tukey's post tests revealed significant differences between the control and inoculated olives with L. plantarum S175 and L. pentosus S100. Higher levels of acidic taste, hardness, and crunchiness than the control and the market sample (control 2) were obtained in fermented olives (Figure 5). Furthermore, the bitterness obtained in the inoculated olives was lower than the control and higher than the market sample (Figure 5). No significant differences in bitterness or crunchiness were obtained between the inoculated olives with L. plantarum $\mathrm{S} 175$ or L. pentosus $\mathrm{S} 100$, but significant differences $(\mathrm{p}<0.05)$ in acidic taste and hardness were observed. Significant differences $(p<0.001)$ were observed between the inoculated (L. plantarum $\mathrm{S} 175$ or L. pentosus $\mathrm{S} 100$ ) and un-inoculated olives (control or control market). The acidic taste, crunchiness and hardness were significantly higher in the inoculated olives than in the controls. However, the inoculated olives showed a bitter taste significantly lower than un-inoculated olives (control) 


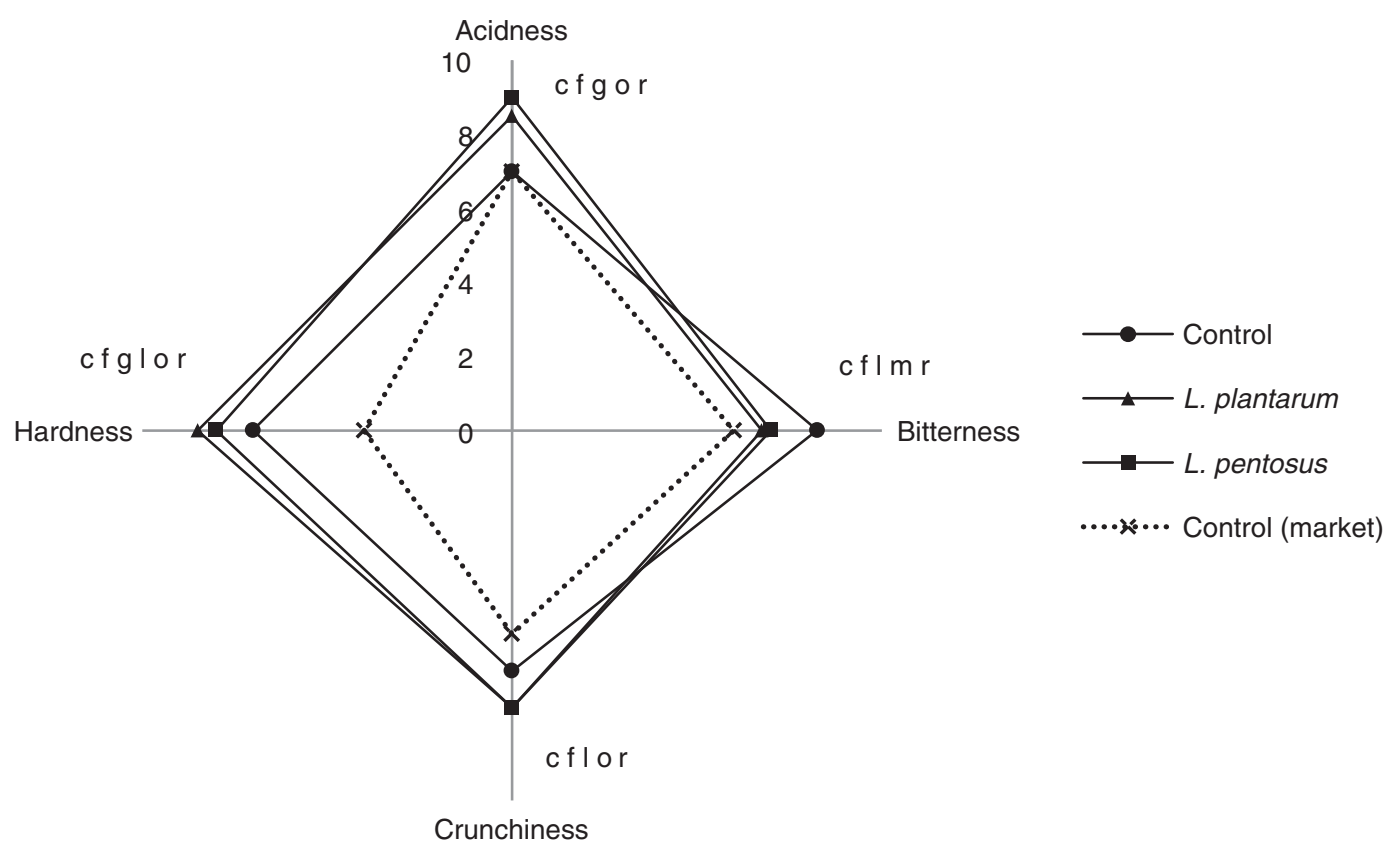

FIgURE 5. Evaluation of some sensory attributes of fermented green olives. - Control: uninoculated green olives (spontaneous fermentation), - L. plantarum: Green olives inoculated with Lactobacillus plantarum S175 strain, - - - L. pentosus: Green olives inoculated with Lactobacillus pentosus S100 strain, ....... Control 2 (market): Green olive market sample (control 2) de-bittered chemically by sodium hydroxide. ${ }^{\text {be }}$ Values (L. plantarum vs Control), ${ }^{\mathrm{def}}$ Values (L. pentosus vs Control), ${ }^{\mathrm{ghi}}$ Values (L. plantarum vs

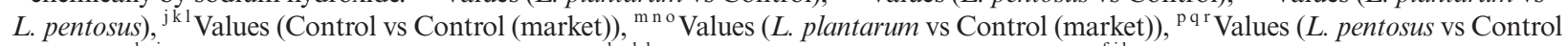
(market)). ${ }^{\text {adgjm p }}$ Values differ significantly $(\mathrm{p}<0.05) .{ }^{\text {beh kn q }}$ Values differ significantly $(\mathrm{p}<0.01) .{ }^{\text {f i i or }}$ Values differ significantly $(\mathrm{p}<0.001)$.

and higher than the market sample (control 2) which was de-bittered chemically by sodium hydroxide. The low bitter taste appreciated by the panelists in inoculated olives may be due to the high biological acidity covering the residual bitterness. This finding indicates the effectiveness of the oleuropeinolytic LAB strains tested in olive de-bittering, but at a lower rate than the chemical de-bittering process. Significant differences in hardness and crunchiness were observed between un-inoculated olives (control) and the market sample (control 2), due mainly to the low quality of the olives of the market sample caused by chemical de-bittering. No significant difference in acidic taste was obtained between the controls, which may be explained by the chemical acidification of the olives. This result is in accordance with that of (Tataridou and Kotzekidou, 2015), who recently reported the possible improvement in sensorial and nutritional characteristics of the final product by using oleuropeinolytic strains of the L. plantarum group as both de-bittering and fermentation agents.

\section{CONCLUSIONS}

The results obtained showed the better performance of LAB strains used in this experiment (L. plantarum S175 and L. pentosus S100) in controlling the natural fermentation process of Moroccan Picholine green olives, by their biological de-bittering and improving the hygienic quality and sensory attributes of the end product, and reducing the bloater spoilage incidence in fermented olives. These LAB strains showed high adaptation to the non alkalitreated Picholine green olive brine environment (at $30{ }^{\circ} \mathrm{C}$ and $5 \% \mathrm{NaCl}$ ), and high biochemical capacity to assure the biodegradation of oleuropein and the dominance of the lactic fermentation process over the other off-odor fermentations and spoilage microorganisms. The application of these selected LAB strains as autochthonous starters for the industrial biological processing of Moroccan Picholine green olives, including de-bittering and fermentation, should lead to economic benefits by improving the quality of fermented olives and reducing olive spoilage.

\section{ACKNOWLEDGEMENTS}

The authors are grateful to the CNRST (PPR 19/2015), the "Commission Universitaire pour le Développement, Belgium" and the Université de Lille 1 for their support.

\section{REFERENCES}

Arroyo-López, FN, Bautista-Gallego J, Domínguez-Manzano J, Romero-Gil V, Rodriguez-Gómez F, García-García P, Garrido-Fernández A, Jiménez-Díaz R. 2012. Formation 
of lactic acid bacteria-yeasts communities on the olive surface during Spanish-style Manzanilla fermentations. Food Microbiol. 32, 295-301. http://dx.doi.org/10.1016/ j.fm.2012.07.003

Arroyo-López FN, Querol A, Bautista-Gallego J, GarridoFernández A. 2008. Role of yeasts in table olive production. Int. J. Food Microbiol. 128, 189-196. http://dx.doi. org/10.1016/j.ijfoodmicro.2008.08.018.

Asehraou A, Peres C, Brito D, Faid M,Serhrouchni M. 2000. Characterization of yeast strains isolated from bloaters of fermented green table olives during storage. Grasas Aceites, 51, 225-229. http://dx.doi.org/10.3989/gya.2000.v51.i4.415.

Ashwell G. 1957. Colorimetric analysis of sugars, Methods Enzymol., Volume 3: Academic Press, pp. 73-105. http:// dx.doi.org/10.1016/S0076-6879(57)03350-9.

Balatsouras G. 1985. Taxonomic and physiological characteristics of the facultative rod type lactic acid bacteria isolated from fermenting green and black olives. Grasas Aceites, 36, 239-249.

Benincasa C, Muccilli S, Amenta M, Perri E, Romeo FV. 2015. Phenolic trend and hygienic quality of green table olives fermented with Lactobacillus plantarum starter culture. Food Chem., 186, 271-276. http://dx.doi.org/10.1016/j. foodchem.2015.02.010

Brenes M, Garcia P, Durán MC, Garrido A. 1993. Concentration of phenolic compounds changes in storage brines of ripe olives. J. Agric. Food Chem. 58, 347-350. http://dx.doi. org/10.1111/j.1365-2621.1993.tb04272.x.

Ciafardini G, Marsilio V, Lanza B, Pozzi N. 1994. Hydrolysis of oleuropein by Lactobacillus plantarum strains associated with olive fermentation. Appl. Environ. Microbiol. 60, 4142-4147

Durán MC., Romero C, García P, Brenes M, Garrido A. 1997. Lactic acid bacteria in table olive fermentations. Grasas Aceites, 48, 297-311. http://dx.doi.org/10.3989/gya.1997. v48.i5.806.

Fernández-Díez MJ, Ramos RC, Garrido A, Heredia AH, Mínguez I, Navarro L.R., Durán MC, González F, Castro AG. 1985. Green Table Olives, in: Derivados, I. d. 1. G. y. s. (ed.) Biotechnology of Table Olives: CSIC, Madrid, pp. 53-123.

Fleming HP, Etchells JL. 1967. Occurrence of an Inhibitor of Lactic Acid Bacteria in Green Olives. Appl. Microbiol. 15, $1178-1184$.

Fleming HP, Walter, WM, Etchells JL. 1973. Antimicrobial Properties of Oleuropein and Products of Its Hydrolysis from Green Olives. Appl. Microbiol. 26, 777-782.

Furneri PM, Marino A, Saija A, Uccella N, Bisignano G. 2002. In vitro antimycoplasmal activity of oleuropein. Int. $J$. Antimicrob. Agents, 20, 293-296. http://dx.doi.org/10.1016/ S0924-8579(02)00181-4.

Garrido-Fernández A, Adams MR, Fernández-Díez, MJ. 1997. Table Olives: Production and processing, London, UK, Chapman \& Hall.

Garrido-Fernández A, Vaughn RH. 1978. Utilization of oleuropein by microorganisms associated with olive fermentations. Can. J. Microbiol. 24, 680-4. http://dx.doi. org/10.1139/m78-114.

Ghabbour N, Lamzira Z, Thonart P, Cidalia P, Markaoui M, Asehraou A. 2011. Selection of oleuropein-degrading lactic acid bacteria strains isolated from fermenting Moroccan green olives. Grasas Aceites, 62, 84-89. http:// dx.doi.org/10.3989/gya.055510.

Hurtado A, Reguant C, Bordons A, Rozes N. 2012. Lactic acid bacteria from fermented table olives. Food Microbiol. 31, 1-8. http://dx.doi.org/10.1016/i.fm.2012.01.006.

Hurtado A, Reguant C, Bordons A, Rozès N. 2010. Evaluation of a single and combined inoculation of a Lactobacillus pentosus starter for processing cv. Arbequina natural green olives. Food Microbiol. 27, 731-740. http://dx.doi. org/10.1016/j.fm.2010.03.006.

Juven B, Samish Z, Henis Y. 1968. Identification of oleuropein as a natural inhibitor of lactic fermentation of green olives. J. Agric. Res. 18, 137-138.

Kaltsa A, Papaliaga D, Papaioannou E, Kotzekidou P. 2015. Characteristics of oleuropeinolytic strains of Lactobacillus plantarum group and influence on phenolic compounds in table olives elaborated under reduced salt conditions.
Food Microbiol. 48, 58-62. http://dx.doi.org/10.1016/ j.fm. 2014.10.016.

Klaenhammer TR, Fremaux C, Hechard Y. 1994. Activité antimicrobienne des bactéries lactiques, in: Lorica, E. (ed.) Bactéries lactiques Tome : 1: De Roissart Het Luquet F. M., pp. 353-366.

Lamzira Z, Asehraou A, Brito D, Oliveira M, Faid M, Peres C. 2005. Reducing the bloater spoilage during lactic fermentation of Moroccan green olives. Food Technol. Biotechnol. 43, 373-377.

Landete JM, Curiel JA, Rodríguez H, de las Rivas B, Muñoz R. 2008. Study of the inhibitory activity of phenolic compounds found in olive products and their degradation by Lactobacillus plantarum strains. Food Chem. 107, 320-326. http://dx.doi.org/10.1016/j.foodchem.2007. 08.043 .

Leal-Sánchez MV, Jiménez Díaz R, Garrido Fernández A, Rejano Navarro L, Ruiz-Barba JL, Sánchez Gómez AH. 2003. Fermentation profile and optimization of green olive fermentationusing Lactobacillus plantarum LPCO10 as a starter culture. Food Microbiol. 20, 421-430. http://dx.doi. org/10.1016/s0740-0020(02)00147-8.

Marsilio V, Lanza B. 1998. Characterisation of an oleuropein degrading strain of Lactobacillus plantarum. Combined effects of compounds present in olive fermenting brines (phenols, glucose and $\mathrm{NaCl}$ ) on bacterial activity. J. Sci. Food Agric. 76, 520-524.

Marsilio V, Lanza B, Pozzi N. 1996. Progress in table olive debittering: Degradationin vitro of oleuropein and its derivatives by Lactobacillus plantarum. J. Am. Oil Chem. Soc. 73, 593-597. http://dx.doi.org/10.1007/bf02518113.

Marsilio V, Seghetti L, Iannucci E, Russi F, Lanza B, Felicioni M. 2005. Use of a lactic acid bacteria starter culture during green olive (Olea europaea L cv Ascolana tenera) processing. J. Sci. Food Agric. 85, 1084-1090. http://dx.doi. org/10.1002/jsfa.2066.

Medina E, García A, Romero C, De Castro A, Brenes M. 2009. Study of the anti-lactic acid bacteria compounds in table olives. Int. J. Food Sci. Technol. 44, 1286-1291. http:// dx.doi.org/10.1111/j.1365-2621.2009.01950.x.

Meilgaard M, Civille GV, Carr BT. 1991. Sensory evaluation techniques, Boca Raton, CRC Press.

Nychas GJE, Tassou SC, Board RG. 1990. Phenolic extract from olives: inhibition of Staphylococcus aureus. Lett. Appl. Microbiol. 10, 217-220. http://dx.doi.org/10.1111/j.1472765x.1990.tb01337.x

Ozdemir Y, Akcay ME, 2011. Olive debittering methods and physical and chemical changes during debittering. Proceedings of National Olive Congress.

Panagou EZ, Schillinger U, Franz CM, Nychas GJ. 2008. Microbiological and biochemical profile of cv. Conservolea naturally black olives during controlled fermentation with selected strains of lactic acid bacteria. Food Microbiol. 25, 348-358. http://dx.doi.org/10.1016/j. fm.2007.10.005.

Panagou EZ, Tassou CC, Katsaboxakis CZ. 2003. Induced lactic acid fermentation of untreated green olives of the Conservolea cultivar by Lactobacillus pentosus. J. Sci. Food Agric. 83, 667-674. http://dx.doi.org/10.1002/ jsfa.1336.

Peres C, Catulo L, Brito D, Pintado C. 2008. Lactobacillus pentosus DSM 16366 starter added to brine as freeze-dried and as culture in the nutritive media for Spanish style green olive production. Grasas Aceites, 59, 234-238. http:// dx.doi.org/10.3989/gya.2008.v59.i3.513.

Randazzo CL, Fava G, Tomaselli F, Romeo FV, Pennino G, Vitello E, Caggia C. 2011. Effect of kaolin and copper based products and of starter cultures on green table olive fermentation. Food Microbiol. 28, 910-919. http://dx.doi. org/10.1016/j.fm.2010.12.004.

Reis J, Paula A. Casarotti S, Penna A. 2012. Lactic acid bacteria antimicrobial compounds: characteristics and applications. Food Engineering Reviews, 4, 124-140. http://dx.doi. org/10.1007/s12393-012-9051-2.

Rodríguez H, Curiel JA, Landete JM, de las Rivas B, de Felipe FL, Gómez-Cordovés C, Mancheño JM, Muñoz R. 2009. 
Food phenolics and lactic acid bacteria. Int. J. Food Microbiol. 132, 79-90. http://dx.doi.org/10.1016/ j.ijfoodmicro.2009. 03.025 .

Romeo F, Poiana M. 2007. Ability of commercially available Lactobacillus strains as starter in brining and debittering of table olives. Acta Alimentaria, 36, 49-60. http://dx.doi. org/10.1556/aalim.36.2007.1.7.

Rozes N, Peres C. 1996. Effect of oleuropein and sodium chloride on viability and metabolism of Lactobacillus plantarum. Appl. Microbiol. Biotechnol. 45, 839-843. http://dx.doi. org/10.1007/s002530050771

Ruiz-Barba JL, Brenes M, Jiménez R, García P, Garrido A. 1993. Inhibition of Lactobacillus plantarum by polyphenols extracted from two different kinds of olive brine. J. Appl. Bacteriol. 74, 15-19. http://dx.doi. org/10.1111/j.1365-2672.1993.tb02990.x.

Ruiz-Barba JL, Garrido A, Jimenez R. 1991. Bactericidal action of oleuropein extracted from green olives against Lactobacillus plantarum. Lett. Appl. Microbiol. 12, 65-68. http://dx.doi.org/10.1111/j.1472-765x.1991.tb00505.x.

Ruiz-Barba JL, Rios-Sanchez RM, Fedriani-Iriso C, Olias JM, Rios JL, Jimenez-Diaz R. 1990. Bactericidal Effect of Phenolic Compounds from Green Olives on Lactobacillus plantarum. Syst. Appl. Microbiol. 13, 199-205. http:// dx.doi.org/10.1016/S0723-2020(11)80170-0.

Sabatini N, Mucciarella MR, Marsilio V. 2008. Volatile compounds in uninoculated and inoculated table olives with Lactobacillus plantarum (Olea europaea L., cv. Moresca and Kalamata). LWT - Food Sci. Technol. 41, 2017-2022. http://dx.doi.org/10.1016/j.lwt.2007.12.002

Sanchez, AH, de Castro, A, Rejano, L. \& Montano, A. 2000. Comparative study on chemical changes in olive juice and brine during green olive fermentation. J. Agric. Food Chem. 48, 5975-80. http://dx.doi.org/10.1021/jf000563u.

Servili M, Settanni L., Veneziani G, Esposto S, Massitti O, Taticchi A, Urbani S, Montedoro, G.F. \& Corsetti, A. 2006. The use of Lactobacillus pentosus $1 \mathrm{MO}$ to shorten the debittering process time of black table olives $(\mathrm{Cv}$. Itrana and Leccino): a pilot-scale application. J. Agric. Food Chem. 54, 3869-3875. http://dx.doi.org/10.1021/jf053206y.

Tataridou M, Kotzekidou P. 2015. Fermentation of table olives by oleuropeinolytic starter culture in reduced salt brines and inactivation of Escherichia coli O157: H7 and Listeria monocytogenes. Int. J. Food Microbiol. 208, 122-130. http:// dx.doi.org/10.1016/j.ijfoodmicro.2015.06.001.

Tsapatsaris S, Kotzekidou P. 2004. Application of central composite design and response surface methodology to the fermentation of olive juice by Lactobacillus plantarum and Debaryomyces hansenii. Int. J. Food Microbiol. 95, 157-168. http://dx.doi.org/10.1016/j.ijfoodmicro. 2004.02.011.

Zago M, Lanza B, Rossetti L, Muzzalupo I, Carminati D, Giraffa, G. 2013. Selection of Lactobacillus plantarum strains to use as starters in fermented table olives: Oleuropeinase activity and phage sensitivity. Food Microbiol. 34, 81-87. http:// dx.doi.org/10.1016/j.fm.2012.11.005. 